\title{
RESPONSE OF TROPICAL FORAGES TO IRRIGATION IN CERRADO/PANTANAL ECOTONE
}

\author{
RESPOSTA DE FORRAGENS TROPICAIS À IRRIGAÇÃO NO ECÓTONO \\ CERRADO/PANTANAL
}

\author{
Lohany Sthéfany da Silva BASSO'; ;rancisco Eduardo TORRES'; \\ Paulo Eduardo TEODORO²; Adriano da Silva LOPES'; \\ Alisson Rodrigo Almeida MARGATTO' ${ }^{1}$, Marcos Jefferson KRAESKI ${ }^{1}$ \\ 1. Universidade Estadual de Mato Grosso do Sul, Aquidauana, MS, Brasil; 2. Universidade Federal de Viçosa, Viçosa, MG, Brasil. \\ eduteodoro@hotmail.com
}

\begin{abstract}
This work aimed to evaluate the irrigation influence on the forage production of Panicum maximum, Pennicetum pupureum, Urochloa brizantha and Urochloa ruziziensis during the rainy and dry seasons in Cerrado-Pantanal ecotone. Trial was conducted at experimental area of irrigated agriculture of Universidade Estadual de Mato Grosso do Sul, Unit of Aquidauana. We assessed the interaction between irrigation versus tropical forage species in the rainy and dry seasons. The first factor is the irrigation or non-irrigation, while the second factor comprises the species. Experimental design used was randomized complete with four replications in factorial scheme $2 \times 4$. There were two forage collections during the dry the rainy" interval for standardization cutting and harvest at 45 days after. Traits evaluated dry matter of leaves (DML), dry matter of stems (DMS), total dry matter (DMT) and leaf/stem ratio (L/S) were assessed. Irrigation management influences the production of the assessed forage species only in dry seasons. Urochloa brizantha is the most recommended forage for the Cerrado-Pantanal ecotone region, due to its high forage production, especially when it comes to sheets. In dry seasons, $P$. purpureum has increased DMT under an irrigated system, but with lower L/S ratio.
\end{abstract}

KEYWORDS: Pennisestum purpureum. Panicum maximum Jacq. Urochloa Brizantha. Urochloa ruziziensis.

\section{INTRODUCTION}

According to IBGE (2012), Brazil has the second largest cattle herd in the world with approximately 212 million heads on a grassland area of 152 million hectares. The State of Mato Grosso do Sul has about 21.5 million heads, being therefore of great importance in the cattle production "ranking", with the municipalities of Corumbá and Ribas do Rio Pardo occupying the first and the third positions, respectively, in cattle production in the country.

In tropical regions, such as Cerrado, forage production is influenced by two distinct periods: the "rainy" periods , from October to March, and the "dry" periods, from June to September. In the rainy periods, high temperatures, long photoperiods and a higher concentration of rainfall favor forage production (TEIXERA et al., 2011). During dry seasons, with the lack of rainfall and other ideal conditions for development, forage suffers from the reduction in uniformity of production, hindering herd food planning and reducing the stocking rate in this period (BRÂNCIO et al., 2003). Water distribution through irrigation can ensure production and enhance forage quality, increasing profitability. Amongst the main forage produced in Brazil, the species Pennisetum purpureum Shun, Panicum maximum Jacq and Urochloa brizantha (Hoscht ex A. Rich) stand out, both because of their high yield potential as well as their adaptability to Cerrado soil conditions (MOREIRA et al., 2007).

P. maximun cv. Mombaça has a cespitose annual growth cycle, with an average height of 1.65 $\mathrm{m}$ and leaves without cerosity, with little hair on the upper surface and slightly purplish stems. It produces around $33 \mathrm{Mg} \mathrm{ha}^{-1}$ year $^{-1}$ of leaf dry matter over 14 days of grazing and 60 days of rest during dry seasons and, 12 days of grazing and 37 of rest during rainy periods (BRÂNCIO et al., 2003). This forage should be well explored during rainy seasons, when growth is more intense and nutritional quality is also better (TORRES et al., 2016).

$P$. purpureum cv. Napier is a perennial forage with high productive potential, however, it requires suitable climatic conditions and fertile soil for its development. It has open clumps, vigorous tillering, thick stems, large leaves and crude protein contents from 10 to $15 \%$ that are obtained from the cutting intervals from 20 to 40 days. If well managed, it can support from 7.0 to 17 animal units ha $^{-1}$ (LIMA et al., 2010).

$U$. brizantha $\mathrm{cv}$. Xaraés has a cespitose growth, about $1.5 \mathrm{~m}$ in height lanceolate and long sheets with little hair and dark-green color. It is 
recommended for areas with rainfall of above 800 $\mathrm{mm}$ per year and average fertility soils, reaching a production of up to $21 \mathrm{tha}^{-1}$ of dry matter. It has fast regrowth, with leaf growth rates in rainy and dry periods of 28.2 and $9.8 \mathrm{~kg} \mathrm{ha}^{-1}$ day $^{-1}$, respectively (EMBRAPA, 2004).

$U$. ruziziensis is a perennial undergrowth forage, with a short rhizome and tender leaves, having 6 to $15 \mathrm{~mm}$ wide and 10 to $25 \mathrm{~cm}$ in length and presence of hair. It is suitable for medium to high fertility soils, with annual rainfall of above 800 $\mathrm{mm}$, and it is quite palatable and well accepted by the animals. It has $8-11 \%$ crude protein in the dry matter and production from 10 to $14 \mathrm{t} \mathrm{ha}^{-1}$ of dry matter per year, but it has low regrowth, so appropriate management must be performed (PEDREIRA et al., 2007).

This work aimed to evaluate the irrigation influence on the forage production of Panicum maximum, Pennicetum pupureum, Urochloa brizantha and Urochloa ruziziensis during the rainy and dry seasons in Cerrado-Pantanal ecotone.

\section{MATERIAL AND METHODS}

Trial was conducted at experimental area of irrigated agriculture of Universidade Estadual de
Mato Grosso do Sul, Unit of Aquidauana (20 $20^{\circ}$ S, $55^{\circ} 48^{\prime} \mathrm{W}$ and average altitude of 191 meters). Region climate according to the Köppen classification is Aw, defined as sub-humid warm tropical, with the rainy season in the summer and dry in winter and average annual rainfall of 1,200 $\mathrm{mm}$. The soil of the area was classified as Ultisol dystrophic sandy texture.

We assessed the interaction between irrigation versus tropical forage species in the rainy and dry seasons. The first factor is the irrigation or non-irrigation, while the second factor comprises the species $P$. maximun cv. Mombaça, $U$. brizantha cv. Xaraés, $U$. ruziziensis and $P$. purpureum cv. Napier. Randomized complete design with four replications was used. The forages $P$. maximum, $U$. brizantha and $U$. ruziziensis were sown in May 5, 2012, the full emergence occurring seven days after sowing, and spending $25 \mathrm{~kg} \mathrm{ha}^{-1}$ of seeds, while $P$. purpureum cv. Napier was vegetatively propagated using $10 \mathrm{t} \mathrm{ha}^{-1}$ of seedlings spaced $0.7 \mathrm{~m}$ between rows. Table 1 shows the chemical soil analysis of the area. Topdressing was performed 30 days after germination, applying $100 \mathrm{~kg} \mathrm{ha}^{-1}$ of nitrogen fertilizer having urea as source.

Table 1. Chemical soil analysis of the área with irrigated and non-irrigated forages in the municipality of Aquidauana, MS.

\begin{tabular}{|c|c|c|c|c|c|c|c|c|c|c|}
\hline $\begin{array}{c}\mathrm{pH} \\
\mathrm{H}_{2} \mathrm{O}\end{array}$ & $\begin{array}{c}\mathrm{P} \\
\mathrm{mg} \mathrm{dm}^{-3}\end{array}$ & $\begin{array}{c}\mathrm{OM} \\
\mathrm{g} \mathrm{dm}^{-3}\end{array}$ & $\mathrm{~K}$ & $\mathrm{Ca}$ & $\begin{array}{l}\mathrm{Mg} \\
\mathrm{mol} \mathrm{d}\end{array}$ & Al & $\mathrm{H}$ & SB & $\mathrm{T}$ & $\begin{array}{l}\mathrm{V} \\
\%\end{array}$ \\
\hline \multicolumn{11}{|c|}{ Irrigated area } \\
\hline 5.44 & 45.84 & 20.27 & 0.19 & 3.55 & 0.9 & 0.15 & 3.51 & 4.64 & 8.3 & 55.9 \\
\hline \multicolumn{11}{|c|}{ Non-irrigated area } \\
\hline 5.15 & 41.3 & 19.74 & 0.2 & 1.6 & 0.5 & 0.0 & 2.8 & 2.3 & 5.1 & 45.1 \\
\hline
\end{tabular}

P: Mehlich ${ }^{-1}$.

In weed control, the application of active ingredient 2,4-D, at $1 \mathrm{~L} \mathrm{ha}^{-1}$ of the commercial product, at 60 days after emergence (DAE), in addition to periodic hand weeding. During this period, there was the occurrence of Mocis latipes, which was controlled by applying the active ingredient deltamethrin, at $0.06 \mathrm{~L} \mathrm{ha}^{-1}$ of the commercial product.

We used the sprinkler irrigation, by center pivot, with $87.2 \%$ Christiansen's Uniformity Coefficient (CUC) and 78.0\% Distribution Uniformity Coefficient (DUC). Irrigated plot consisted of 0.8 ha, where each forage occupied an area of 0.2 ha in "pizza" format with dimensions of $70 \mathrm{~m}$ (towards the pivot ray) and $55 \mathrm{~m}$ wide at the end. The non-irrigated forages occupied area of $1170 \mathrm{~m}^{2}$, each with $293 \mathrm{~m}^{2}$

Irrigation managment started at the date of cultivars emergence using the daily estimate reference evapotranspiration (ETo) based on Penman-Monteith method (Equation 1). It was considered as water depletion factor $50 \%$ the soil water holding capacity. The values related to the effective root zone $(\mathrm{Z})$ and the crop coefficient $(\mathrm{Kc})$ were $40 \mathrm{~cm}$ and 1.05 , respectively (ALLEN et al., 1998).

$$
\mathrm{ETo}_{(\mathrm{PM})}=\frac{0,408 \Delta(\mathrm{Rn}-\mathrm{G})+\gamma\left(\frac{900 \mathrm{U}_{2}}{\mathrm{~T}+273}\right)(\mathrm{es}-\mathrm{ea})}{\Delta+\gamma\left(1+0,34 \mathrm{U}_{2}\right)}
$$


Where in:

$\mathrm{ETo}_{(\mathrm{PM})}$ is the reference evapotranspiration by Penman-Monteith method, $\mathrm{mm} \mathrm{day}^{-1} ; \Delta$ is the declination of the water vapor saturation curve, $\mathrm{kPa}$ ${ }^{\circ} \mathrm{C}^{-1}$; $\mathrm{Rn}$ is the net radiation, $\mathrm{MJ} \mathrm{m}{ }^{-2} \mathrm{day}^{-1} ; \mathrm{G}$ is the heat flow in the soil, MJ m${ }^{-2} \mathrm{day}^{-1} ; \gamma$ is the psychrometric constant (0.0659823); $\mathrm{U}_{2}$ is the average wind speed $2 \mathrm{~m}$ above the soil surface, $\mathrm{m} \mathrm{s}^{-}$ ${ }^{1}$; $\mathrm{T}$ is the average air temperature, ${ }^{\circ} \mathrm{C}$; es is the vapor saturation pressure, $\mathrm{kPa}$; ea is the vapor current pressure, $\mathrm{kPa}$
For carrying out the forage collection, mechanical mowing were made to $25 \mathrm{~cm}$ for standardization of forage. After 45 days, there was the collection of samples, which were composed by the shoot and demarcated by a square of $0.5 \mathrm{~m}$ side, released at random on the plots by collection of five samples per plot. The first mowing was held on 15 July 2013 and collecting in the dry season on August 31, 2013; he second mowing was conducted on January 7, 2014 and collecting during the rainy season on February 21, 2014. The corresponding climatological data between the range of each mowing and cuts are shown in Table 2.

Table 2. Equivalent climatological balance between mowing and cutting of forage during the rainy and dry seasons.

\begin{tabular}{cccccc}
\hline Season & Irrigation & $\begin{array}{c}\text { Average temperature } \\
\left({ }^{\circ} \mathrm{C}\right)\end{array}$ & $\begin{array}{c}\text { Relative Humidity } \\
(\%)\end{array}$ & $\begin{array}{c}\text { Rainfall } \\
(\mathrm{mm})\end{array}$ & $\begin{array}{c}\text { Applied irrigation depth } \\
(\mathrm{mm})\end{array}$ \\
\hline \multirow{2}{*}{ Dry } & $\begin{array}{c}\text { Irrigated } \\
\text { Non- } \\
\text { irrigated }\end{array}$ & 19.41 & 62,74 & 3.60 & 35.80 \\
Rainy & $\begin{array}{c}\text { Irrigated } \\
\text { Non- } \\
\text { irrigated }\end{array}$ & 26.31 & 79,22 & 233.80 & ------- \\
\hline
\end{tabular}

After each collection, manual separation of stems, leaves and dead material was performed. For determining dry matter (DM), leaves and stems were taken to an oven with forced air circulation at $65^{\circ} \mathrm{C}$ for 72 hours. After this period, dry matter of leaves (DML), dry matter of stems (DMS), total dry matter (DMT) and leaf/stem ratio (L/S) were assessed.

Initially, the data normality was verified by Shapiro-Wilk test, being it subjected to analyzes of individual variances for each area, and then, assessment of mean squares of the residues was carried out (BANZATTO; KRONKA, 2006) for observing the normal distribution of data. We performed the joint analysis of variance of the areas, and the averages was compared by Tukey test at $5 \%$ probability. All analyzes were performed with Sisvar 5.3 statistical software (FERREIRA, 2011).

\section{RESULTS AND DISCUSSION}

For all variables analyzed in this trial, the relationship between the mean square of joint analysis of variance of the experiments did not exceed the ratio $7: 1$, allowing following implementing the joint analysis of experiments and comparison of irrigation managements (BANZATTO; KRONKA, 2006). In the dry season, there was significance $(\mathrm{p}<0.01)$ between the irrigation (I), species $(\mathrm{S})$ and $\mathrm{I} x \mathrm{~S}$ for all variables (Table 3). This indicates that in this period there was differential response of each forage species depending on irrigation management.

Table 3. F values for the variables dry mattert of leaves, stems and total (DML, DMS and DMT,respectively) and leaf/stem ratio $(\mathrm{L} / \mathrm{S})$ depending on irrigation use $(\mathrm{I})$, tropical forage species $(\mathrm{S})$ and I x S for dry season. Aquidauana, MS, 2014.

\begin{tabular}{ccccc}
\hline Sources of variation & DML & DMS & DMT & L/S \\
\hline Irrigation $(\mathrm{I})$ & $29.82^{* *}$ & $25.24 * *$ & $47.17 * *$ & $4.29 * *$ \\
Species $(\mathrm{S})$ & $4.70^{* *}$ & $12.85^{* *}$ & $13.30^{* *}$ & $9.21^{* *}$ \\
I x S & $10.13^{* *}$ & $15.37 * *$ & $21.24 * *$ & $4.26 * *$ \\
\hline CV $(\%)$ & 25.18 & 31.81 & 21.41 & 24.00 \\
\hline
\end{tabular}

**: significant at $1 \%$ probability by F-test.

On $P$. maximun e $U$. ruziziensis under irrigation, did not differ for the variable DML
(Table 4), indicating that the leaf production is not adversely affected by the dry season conditions in 
the Cerrado/Pantanal ecotone region. Irrigation use in $P$. purpureum and $U$. brizantha provides an increase of 178 and 69\%, respectively, in this variable, allowing to infer that these species are highly responsive the irrigation use in this region. With the irrigation use, $P$. purpureum had the highest DML production, while without irrigation there was no difference between tropical forage species.
Evaluating total biomass production, Garcia et al. (2011) found that the Mombaça leaves proportion was higher than that the elephant grass, in disagreement this with work. The authors also observed that this difference is conferred by cultivar tillering characteristic, citing Parsons (1988), asserting that axillary or side tillers of the Napier cultivar favors the stem elongation, contrary to cultivate Mombaça which is basal, resulting in larger sheets.

Table 4. Deployment of significant interaction between irrigation (I) and tropical forage species (S) for the variable dry mass of leaves (DML, $\mathrm{kg} \mathrm{ha}^{-1}$ ), assessed in the dry season. Aquidauana, MS, 2013.

\begin{tabular}{ccccc}
\hline Species & Irrigated & Non-irrigated & Mean & LSD \\
\hline Panicum maximun & $1,900 \mathrm{Ab}$ & $2,075 \mathrm{Aa}$ & 1,988 & \\
Pennisetum purpureum & $3,618 \mathrm{Aa}$ & $1,302 \mathrm{Ba}$ & 2,460 & 886 \\
Urochloa brizantha & $2,021 \mathrm{Ab}$ & $1,199 \mathrm{Ba}$ & 1,610 & \\
Urochloa ruziziensis & $2,462 \mathrm{Ab}$ & $1,853 \mathrm{Aa}$ & 2,158 & ------- \\
\hline Mean & 2,500 & 1,607 & ------- & --- \\
LSD & & & 666 & -----
\end{tabular}

Means followed by equal uppercase in the line and lowercase letters in the column do not differ by Tukey's test at 5\% probability. LSD: least significant difference.

Irrigation enhanced $380 \%$ in the production of DMS in $P$. purpureum, but in other species, irrigation management does not influence this variable (Table 5). In irrigated conditions, $P$. purpureum obtained the highest DMS production, however, under rainy season conditions,
$P$. maximun and $U$. ruziziensis obtained the highest average for this variable. $P$. purpureum obtained the highest DMT, DML and DMS was higher than the other cultivars, corroborating other results (GARCIA et al., 2011; RIBEIRO et al., 2009 e LOPES et al., 2005).

Table 5. Deployment of significant interaction between irrigation (I) and tropical forage species (S) for the variable dry mass of stems (DMS, $\mathrm{kg} \mathrm{ha}^{-1}$ ), assessed in the dry season. Aquidauana, MS, 2013.

\begin{tabular}{|c|c|c|c|c|}
\hline Species & Irrigated & Non-irrigated & Mean & LSD \\
\hline Panicum maximun & $1,209 \mathrm{Ac}$ & $1,495 \mathrm{Aa}$ & 1,352 & \multirow{4}{*}{832} \\
\hline Pennisetum purpureum & $3,157 \mathrm{Aa}$ & $658 \mathrm{Bb}$ & 1,908 & \\
\hline Urochloa brizantha & $995 \mathrm{Ac}$ & $657 \mathrm{Ab}$ & 826 & \\
\hline Urochloa ruziziensis & $2,286 \mathrm{Ab}$ & $1,752 \mathrm{Aa}$ & 2,019 & \\
\hline Mean & 1,912 & 1,141 & ------ & ------ \\
\hline LSD & \multicolumn{2}{|c|}{625} & ------- & ------- \\
\hline
\end{tabular}

Means followed by equal uppercase in the line and lowercase letters in the column do not differ by Tukey's test at 5\% probability. LSD: least significant difference.

Silva and Nascimento Junior (2008) concluded that tropical and subtropical forages begin the process of regrowth and forage production by tissue accumulation derived from leaves. Only when light restriction occurs (above 95\% light interception sward) or when at the flowering the plant beginning the stem elongation, responsible for the shading and senescence of basal leaves, resulting in increased proportion of stems and dead material in the forage mass.

$P$. purpureum and $U$. brizantha in dry season for DMT (Table 6), unlike the rainy season, which indicates that this condition for the total dry matter production is not affected. For P. maximun, there was no increase in production in relation to the irrigation use compared to without irrigation, allowing to infer that for the others was not different. Irrigation use for $P$. purpureum, $U$. brizantha and $U$. ruziziensis provided increases in total dry matter production. With the irrigation, $P$. purpureum showed higher DMT.

Irrigation did not affect the DMT production in $P$. maximun, however, in $P$. purpureum, $U$. brizantha and $U$. ruziziensis provided, respectively, an increase of $246,62.5$ and $32.7 \%$ on DMT production (Table 6), indicating responsiveness of 
these forage species to irrigation in dry season. Under irrigation, $P$. purpureum had the highest DMT production, however, under non-irrigated conditions, $P$. maximun and $U$. ruziziensis produced higher amount of forage, and it is particularly interesting because this is the period of lower forage allowance.

Table 6. Deployment of significant interaction between irrigation (I) and tropical forage species (S) for the variable total dry mass (DMT, $\mathrm{kg} \mathrm{ha}^{-1}$ ), assessed in the dry season. Aquidauana, MS, 2013.

\begin{tabular}{ccccc}
\hline Species & Irrigated & Non-irrigated & Mean & LSD \\
\hline Panicum maximun & $3,109 \mathrm{Ac}$ & $3,569 \mathrm{Aa}$ & 3,339 & \\
Pennisetum purpureum & $6,774 \mathrm{Aa}$ & $1,959 \mathrm{Bb}$ & 4,367 & 1,313 \\
Urochloa brizantha & $3,016 \mathrm{Ac}$ & $1,856 \mathrm{Bb}$ & 2,436 & \\
Urochloa ruziziensis & $4,748 \mathrm{Ab}$ & $3,606 \mathrm{Ba}$ & 4,177 & ------- \\
\hline Mean & 4,412 & 2,748 & ------- & ------ \\
\hline
\end{tabular}

Means followed by equal uppercase in the line and lowercase letters in the column do not differ by Tukey's test at 5\% probability. LSD: least significant difference.

Assessing the irrigation influence on $P$. purpureum cv. Napier and $P$. maximun cv. Mombaça, Ribeiro et al. (2009) verified that Mombaça and Napier presented greater DMT availability when submitted to irrigation. They also reported that the Napier DMT availability is related to the higher amount of stem produced by this forage, a fact that can be observed in this work for DMT obtained by Napier regarding the others.

Production capacity of the Xaraés cultivar was evident in this work. Its values are similar to the values of Mombaça cultivar, especially in adopting irrigation system. Studies comparing the productivity of Xaraés with other cultivars are scarce in the literature. In testing sites, it presented high forage production, reaching $21 \mathrm{t} \mathrm{ha}^{-1}$ of dry matter, with $30 \%$ of this productivity in the dry season (VALLE et al., 2001). Xaraés can also be an alternative for use even in non-irrigated conditions, because its adaptation to soils of medium fertility, low water requirement and the good results presented in this study classified it as a good alternative for agricultural regions with lower rainfall (SILVA JUNIOR et al., 2013). Pedreira et al. (2007), assessing Xaraés cultivar under rotational grazing strategies, found that the monthly daily rate of forage accumulation, for the months of October and November, was between 161.7 and $132.1 \mathrm{~kg} \mathrm{ha}^{-}$ ${ }^{1}$ day $^{-1}$, values similar to the observed in this study.

$\mathrm{L} / \mathrm{S}$ ratio quantifies the number of sheets in the DMT, and since in these organs are the most portion of the digestible crude protein, the analysis of this variable it is necessary for recommending forage species for cultivation. Irrigation influenced only $P$. purpureum, which in irrigated conditions has lower L/S ratio, indicating that the considerable increase in forage production of this species is mainly by the increase in DMT (Table 7).

Table 7. Deployment of significant interaction between irrigation (I) and tropical forage species (S) for leaf/stem ratio (L/S). Aquidauana, MS, 2015.

\begin{tabular}{ccccc}
\hline Species & Irrigated & Non-irrigated & Mean & LSD \\
\hline Panicum maximun & $1.56 \mathrm{Ab}$ & $1.41 \mathrm{Ab}$ & 1.49 & \\
Pennisetum purpureum & $1.21 \mathrm{Bb}$ & $1.98 \mathrm{Aa}$ & 1.59 & 0.54 \\
Urochloa brizantha & $2.10 \mathrm{Aa}$ & $1.83 \mathrm{Aa}$ & 1.97 & \\
Urochloa ruziziensis & $1.16 \mathrm{Ab}$ & $1.05 \mathrm{Ab}$ & 1.11 & ------- \\
\hline Mean & 1.51 & 1.56 & ------ & ------ \\
LSD & & 0.48 & --- &
\end{tabular}

Means followed by equal uppercase in the line and lowercase letters in the column do not differ by Tukey's test at 5\% probability. LSD: least significant difference.

When assessing the performance of the species within each irrigation management, we verified that regardless the management adopted, $U$. brizantha obtained the higher L/S ration, but did not differ from $P$. purpureum under non-irrigated condition. In this way, high DMT production by $U$. brizantha cv. Xaraés allows inferring that this species has a high adaptability to the CerradoPantanal ecotone region, can be recommended to farmers both for irrigated and non-irrigated cultivation. 
Pinto et al. (1994), reported that high L/S ratio is a very important attribute from a nutritional point of view, since it represents forage with higher protein content and digestibility. Pedreira et al. (2007) showed that the highest average rates of forage accumulation to Xaraés cultivar were observed in the months of September, October and December, due to post-grazing fertilizing and the season of high temperature and rainfall availability, reinforcing the high productivity found in this trial, even in non-irrigated area. During the rainy season, irrigation did not influence any of the evaluated variables (Table 8). This occurred due to the rainfall during this period $(233.80 \mathrm{~mm})$, which caused no need for irrigation.

Table 8. F values for the variables dry mattert of leaves, stems and total (DML, DMS and DMT,respectively) and leaf/stem ratio (L/S) depending on irrigation use (I), tropical forage species (S) and I x S for rainy season. Aquidauana, MS, 2015.

\begin{tabular}{ccccc}
\hline Sources of variation & DML & DMS & DMT & L/S \\
\hline Irrigation (I) & $1.70^{\mathrm{ns}}$ & $0.01^{\mathrm{ns}}$ & $1.36^{\mathrm{ns}}$ & $0.99^{\mathrm{ns}}$ \\
Species (S) & $2.41^{\mathrm{ns}}$ & $15.08^{* *}$ & $5.78^{* *}$ & $1.97^{\mathrm{ns}}$ \\
I x S & $1.40^{\mathrm{ns}}$ & $1.04^{\mathrm{ns}}$ & $1.57^{\mathrm{ns}}$ & $1.34^{\mathrm{ns}}$ \\
\hline CV $(\%)$ & 18.11 & 14.72 & 17.76 & 15.01 \\
\hline
\end{tabular}

${ }_{\mathrm{ns}}$ and $* *$ : not significant and significant at $1 \%$ probability by F-test, respectively.

For the rainy season, lack of different results (DML, DMS, DMT and L/S), under irrigated management, is due to two important factors to Forage Crops: temperature and rainfall, especially in the Cerrado region (MULLER et al., 2002). In the averages of these factors, we observed that the levels for the crops requirements were adequate, considering that the temperature and rainfall were near or above $20^{\circ} \mathrm{C}$ and $200 \mathrm{~mm}$, respectively, favoring a positive plant development during the assessed period.

There were significant differences between the species for the variables DMS and DMT (Table 9). P. purpureum obtained the higher DMS and DMT, but not differed statistically from $P$. maximun and $U$. brizantha for total forage production.

Table 9. Average values of the variables dry matter of stem and total dry matter (DMS and DMT, respectively) depending on the tropical forage species. Aquidauana, MS, 2015.

\begin{tabular}{ccc}
\hline Species & DMS & DMT \\
\hline Panicum maximun & $3,681 \mathrm{~b}$ & $\mathrm{~kg} \mathrm{ha}^{-1}$ \\
Pennisetum purpureum & $11,744 \mathrm{a}$ & $15,122 \mathrm{a}$ \\
Urochloa brizantha & $3,844 \mathrm{~b}$ & $16,558 \mathrm{a}$ \\
Urochloa ruziziensis & $2,313 \mathrm{~b}$ & $9,984 \mathrm{a}$ \\
LSD & 4,233 & $4,830 \mathrm{~b}$ \\
\hline
\end{tabular}

Means followed by equal uppercase in the line and lowercase letters in the column do not differ by Tukey's test at 5\% probability. LSD: least significant difference.

According to EMBRAPA (1999), Pannicum maximum cv. Tanzânia shows good tolerance to drought and cold, and its water requirement varies between 800 and $1500 \mathrm{~mm}$ per year. According to Souza Filho (1994), water requirement by Brachiaria brizantha (Urochloa) cv. Marandu ranges between 800 and $1200 \mathrm{~mm}$ per year and shows high resistance to dry. These cultivars belonging to genera very close to those used in this trial, fact that may to explain the absence of statistical difference between the irrigated and nonirrigated systems. Therefore, rainfall was enough to supply the crop water requirement.

\section{CONCLUSIONS}

Irrigation management influences the production of the assessed forage species only in dry seasons.

Urochloa brizantha is the most recommended forage for the Cerrado-Pantanal ecotone region, due to its high forage production, especially when it comes to sheets.

In dry seasons, $P$. purpureum has increased DMT under an irrigated system, but with lower L/S ratio. 
RESUMO: O objetivo desta pesquisa foi avaliar a influência da irrigação sobre a produção de forragem das espécies Panicum maximum cv. Mombaça, Pennisetum pupureum cv. Napier, Urocloa brizantha cv. Xaraés e Urochloa ruziziensis, nas épocas das “águas” e seca na região do ecótono Cerrado-Pantanal. A pesquisa foi desenvolvida na área experimental de agricultura irrigada e fitotecnia da Universidade Estadual de Mato Grosso do Sul, Unidade Universitária de Aquidauana. Foi avaliada a interação entre irrigação versus espécies forrageiras tropicais nas épocas das águas e da seca. O primeiro fator consistiu na utilização ou não da irrigação, enquanto o segundo fator foi composto pelas espécies. Foi utilizado delineamento inteiramente casualizados com quatro repetições no esquema fatorial $2 \times 4$. Foram realizadas duas coletas de forragem nas épocas seca e das "águas" com intervalo para roçada de uniformização e a colheita 45 dias após, avaliando os caracteres massa seca das folhas (MSF), massa seca dos colmos (MSC), massa seca total (MST) e a relação folha/colmo (F/C). A irrigação influencia a produção de forragem das espécies avaliadas somente na época da seca. A espécie Urochloa brizantha é a mais recomendada para a região do ecótono Cerrado-Pantanal devido a sua alta produção de forragem, sobretudo de folhas. Na seca, Pennisetum purpureum apresenta maior MST quando irrigado, porém com menor relação F/C.

PALAVRAS-CHAVE: Pennisestum purpureum. Panicum maximum Jacq. Urochloa Brizantha. Urochloa ruziziensis.

\section{REFERENCES}

ALLEN, R. G.; PEREIRA, L. S.; RAES, D.; SMITH, M. Crop evapotranspiration: guidelines for computing crop water requirements. Rome: FAO, 1998. (Irrigation and drainage paper, 56).

BANZATTO, D. A.; KRONKA, S. N. Experimentação agrícola. 4. ed. Jaboticabal: FUNEP, 2006. 237p.

BRÂNCIO, P. A.; EUCLIDES, V. P. B.; JÚNIOR, D. N.; FONSECA, D. M.; ROBERTO GIOLO DE ALMEIDA, R. G.; MOTTA, M. C.; BARBOSA, R. A. Avaliação de Três Cultivares de Panicum maximum Jacq. sob Pastejo: Disponibilidade de Forragem, Altura do Resíduo Pós-Pastejo e Participação de Folhas, Colmos e Material Morto. Revista Brasileira de Zootecnia, Viçosa, v. 32, n. 1, p. 55-63, 2003. http://dx.doi.org/10.1590/s1516-35982003000100007

SILVA, S. C.; NACIMENTO JUNIOR, R. D. Aspectos agronômicos para produção intensiva de leite em pasto. Cadernos Técnicos de Veterinária e Zootecnia, Belo Horizonte, v. 56, p. 44-83, 2008.

EMBRAPA - Empresa Brasileira de pesquisa agropecuária. O Capim-Xaraés (Brachiariabrizantha cv. Xaraés) na Diversificação das Pastagens de Braquiária. Campo Grande-MS. 2004. Folder.

EMBRAPA. Sistema Brasileiro de Classificação de Solos. Centro Nacional de Pesquisa em Solos, BrasíliaDF: Embrapa-SPI; Rio de Janeiro-RJ: Embrapa-Solos, 2013. 353 p.

EMBRAPA. Centro Nacional de Pesquisa de Gado de Corte (Campo Grande). Tanzânia - 1. Campo Grande, MS: EMBRAPA - CNPGC, 1999. Folder.

FERREIRA, D. F. Sisvar: a computer statistical analysis system. Ciência e Agrotecnologia, Lavras, v. 35, n. 6, p. 1039-1042, 2011.

GARCIA, C. S.; FERNANDES, A. M.; FONTES, C. A. A.; VIEIRA, R. A. M.; SANT’ANA, N. F.; PIMENTEL, V. A. Desempenho de novilhos mantidos em pastagens de capim-elefante e capim-mombaça. Revista Brasileira de Zootecnia, Viçosa, v. 40, n. 2, p. 403-410, 2011.

IBGE - Instituto Brasileiro de Geografia e Estatística. Pesquisa Pecuária Municipal (1974-2009). Disponível em:< http://www.sidra.ibge.gov.br/bda/tabela/protabl.asp?c=73\&z=p\&o=23\&i=P >. Acesso em 02 dez. 2014. 
LIMA, E. S.; SILVA, J. F. C.; VÁSQUEZ, H. M.; ANDRADE, E. N. DEMINICIS, B. B.; MORAIS, J.P.G.; COSTA, D. P. B.; ARAÚJO, S. A. C. Características agronômicas e nutritivas das principais cultivares de capim-efefante do Brasil. Veterinária e Zootecnia, Botucatu, v. 23, p. 324-334, 2010.

LOPES, R. S.; FONSECA, D. M.; OLIVEIRA, R. A.; ANDRADE, A. C.; NASCIMENTO JÚNIOR, D.; MASCARENHAS, A. G.Efeito da irrigação e adubação na disponibilidade e composição bromatológica da massa seca de lâminas foliares de capim-elefante. Revista Brasileira Zootecnia, v. 34, n. 1, p. 20-29, 2005. http://dx.doi.org/10.1590/S1516-35982005000100003

MOREIRA, A. L.; REIS, R. A.; RUGGIERI, A. C.; SARAN, A. J. Avaliação de forrageiras de inverno irrigadas sob pastejo. Ciência Agrotecnologia, Lavras, v. 31, n. 6, p. 1838-1844, 2007.

MÜLLER, M. S.; FANCELI, A. L.; DOURADO-NETO, D.; GARCÍA, A. G. y; OVEJERO, R. F. L. Produtividade do Panicum maximum cv. mombaça irrigado, sob pastejo rotacionado. Scientia Agricola, Piracicaba, v. 59, n. 3, p. 427-433, 2002.

PEDREIRA, B. C.; PEDREIRA, C. G. S.; SILVA, S. C.; Estrutura do dossel e acúmulo de forragem de Brachiaria brizantha cultivar Xaraés em resposta a estratégias de pastejo. Pesquisa Agropecuária Brasileira, Brasília, v. 42, n. 2, p. 281-287, 2007. http://dx.doi.org/10.1590/S0100-204X2007000200018

PINTO, J. C.; GOMIDE, J. A.; MAESTRI, M. Produção de matéria seca e relação folha/caule de gramíneas forrageiras tropicais, cultivadas em vasos, com duas doses de nitrogênio. Revista Brasileira de Zootecnia, Viçosa, v. 23, n. 3, p. 313-326, 1994.

RIBEIRO, E. G.; FONTES, C. A.; PALIERAQUI, J. G. B.; CÓSER, A. C.; MARTINS, C. E.; SILVA, R. C.; Influência da irrigação, nas épocas seca e chuvosa, na produção e composição química dos capins napier e mombaça em sistema de lotação intermitente. Revista Brasileira de Zootecnia, Viçosa, v. 38, n. 8, p. 1432$1442,2009$.

SILVA JUNIOR, C. A.; TORRES, F. E.; TEODORO, P. E.; SILVA, G. F. C.; SILVA, E. S. Development of Cultivars Brachiaria brizantha in Ecotone Cerrado-pantanal under Different Periods. Journal of Agronomy, New York, v. 12, p. 130-137, 2013. http://dx.doi.org/10.3923/ja.2013.130.137

SOUZA FILHO, C. V. S. Recomendações de espécies e variedades de Brachiaria para diferentes condições. In: SIM-PÓSIO SOBRE MANEJO DA PASTAGEM, 11, 1994, Piracicaba. Anais... Piracicaba: FEALQ, p. 25-48, 1994.

TEIXEIRA, F. A.; BONOMO, P., AURELIANO JOSÉ VIEIRA PIRES, A. J. V.; SILVA, F. F.; FRIES, D. D.; HORA, D. S. Produção anual e qualidade de pastagem de Brachiaria decumbens diferida e estratégias de adubação nitrogenada. Animal Sciences, Maringá, v. 33, n. 3, p. 241-248, 2011.

http://dx.doi.org/10.4025/actascianimsci.v33i3.10194

TORRES, F. E.; TEODORO, P. E.; BENITES, S. B.; OLIVEIRA, E. P.; CORREA, C. C. G.; SILVA, F. A. Number of cuts for estimating forage productivity in P. maximum. Bioscience Journal, Uberlândia, v. 32, p. 172-178, 2016. http://dx.doi.org/10.14393/BJ-v32n1a2016-29307

VALLE, C. B.; EUCLIDES, V. P. B., MACEDO, M. C. M. Selecting new Brachiaria for Brazilian pastures. In: INTERNATIONAL GRASSALAND CONGRESS, 19. São Pedro. Anais... Piracicaba: Escola superior de Agricultura "Luiz de Queiroz", p. 13-14, 2001. 